\title{
A Review of the Dermatological Complications of Giant Cell Arteritis
}

This article was published in the following Dove Press journal:

Clinical, Cosmetic and Investigational Dermatology

\author{
Diana Prieto-Peña ${ }^{1}{ }^{1}$ \\ Santos Castañeda ${ }^{2,3}$ \\ Belén Atienza-Mateo' \\ Ricardo Blanco (D) ${ }^{\prime}$ \\ Miguel Ángel González- \\ Gay (D) ${ }^{1,4,5}$
}

'Department of Rheumatology, Research Group on Genetic Epidemiology and Atherosclerosis in Systemic Diseases and in Metabolic Bone Diseases of the Musculoskeletal System, IDIVAL, Hospital Universitario Marqués de Valdecilla, Santander, Spain; ${ }^{2}$ Department of Rheumatology, H. Universitario de La Princesa, IIS-Princesa, Madrid, Spain; ${ }^{3}$ Cátedra UAM-ROCHE, EPID-Future, Universidad Autónoma Madrid (UAM), Madrid, Spain; ${ }^{4}$ School of Medicine, Universidad de Cantabria, Santander, Spain; ${ }^{5}$ Cardiovascular Pathophysiology and Genomics Research Unit, School of Physiology, Faculty of Health Sciences, University of the Witwatersrand, Johannesburg, South Africa
Correspondence: Miguel Ángel González-Gay

Department of Rheumatology, Research Group on Genetic Epidemiology and Atherosclerosis in Systemic Diseases and in Metabolic Bone Diseases of the Musculoskeletal System, IDIVAL, Hospital Universitario Marqués de Valdecilla, Avenida Valdecilla $s / n$, Santander, 39008, Spain

Email miguelaggay@hotmail.com

\begin{abstract}
Giant cell arteritis (GCA) is characterized by granulomatous inflammation of large and medium-sized vessels. It is the most common vasculitis among elderly people in Europe and North America. GCA usually presents with ischemic cranial manifestations such as headache, scalp tenderness, visual manifestations, and claudication of the tongue and jaw. Thickness and tenderness of temporal arteries are the most recognizable signs of GCA on physical examination. Laboratory tests usually show raised acute phase reactants. Skin manifestations are uncommon in GCA and are rarely found as a presenting symptom of GCA. Necrosis of the scalp and tongue is the most common ischemic cutaneous manifestation of GCA. Although infrequent, when present it reflects severe affection and poor prognosis of GCA. Panniculitis-like lesions have been reported in the setting of GCA, with nodules being the most common finding. Other entities, such as generalized granuloma annulare or basal cell carcinoma have been occasionally described in GCA patients. Prompt recognition and initiation of therapy are crucial to prevent serious complications of GCA. When high suspicion of GCA exists, immediate administration of glucocorticoids is recommended. It is advisable to refer the patient to a specialist GCA team for further multidisciplinary assessment.
\end{abstract}

Keywords: giant cell arteritis, cutaneous manifestations, skin, vasculitis

\section{Introduction}

Giant cell arteritis (GCA) is the most common vasculitis among elderly people from Europe and North America. ${ }^{1}$ It is characterized by granulomatous inflammation of large and medium vessels with special tropism for the branches of the

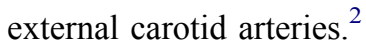

GCA mainly affects patients older than 50 years with an incidence ranging from 5.8 to $31.3 / 100,000$ and prevalence of $30.4 / 100,000 .{ }^{1}$ Environmental factors in patients genetically predisposed may be triggers for the development of GCA. In this regard, a strong association of GCA with HLA class II molecules has been described, particularly with $H L A-D R B 1 * 04$ alleles. $^{3-5}$

The immunopathology of GCA is complex and still not completely understood. Growing evidence support that GCA is a T-cell driven disease. ${ }^{6,7}$ In this regard, type 1 helper T cells (Th1) and type 17 helper T cells (Th17) seem to play a pivotal role in the pathogenesis of GCA. Th-17 inflammatory pathway and related cytokines, such as interleukin (IL)-6, have been linked to the systemic inflammatory symptoms of GCA. Th1 response is associated with the production of interferongamma (IFN-y) and granuloma formation being responsible for the ischemic manifestations of the disease. 6,7 
The classic clinical pattern of GCA consists of ischemic cranial manifestations such as headache, scalp tenderness, visual manifestations, and tongue and jaw claudication. ${ }^{8}$ The most fearsome complication of GCA is irreversible vision loss that can occur in up to $20 \%$ of GCA patients. ${ }^{9,10}$ Strokes have been also described in severe cases of GCA, particularly affecting the vertebrobasilar territories. ${ }^{11}$ GCA is often associated with polymyalgia rheumatica (PMR), which is characterized by pain and stiffness affecting mainly the arms and shoulder girdle, often associated with pain in the hips and pelvic girdle and neck. ${ }^{12}$ Also, systemic inflammatory symptoms, including asthenia, weight loss, or fever may be present. ${ }^{8}$ In recent years, the advent of new imaging techniques has revealed that GCA can also affect extracranial large vessels, even in the absence of classic cranial GCA symptoms. ${ }^{13}$ GCA patients with predominant extracranial large vessel affection are usually younger at diagnosis and present more commonly with refractory features of PMR, fever of unknown origin, constitutional symptoms, and/or limb claudication. ${ }^{14-16}$

Cutaneous manifestations are uncommon in GCA and are rarely found as the presenting symptom of GCA. Most of them, particularly those caused by severe ischemia, are a consequence of the delay in the diagnosis and treatment of GCA.

Literature on cutaneous manifestations of GCA is scarce. ${ }^{17,18}$ Kinmont and McCallum conducted the first extensive review on the dermatological lesions in patients with GCA in $1964 .{ }^{19}$ The most common finding described was the presence of tender nodules on the surface of prominent, tortuous temporal arteries. Scalp and tongue necrosis were reported in patients with severe GCA. Other non-specific lesions included purpura, urticaria, and ulcers in the legs.

Currently, ischemic cutaneous lesions are rarely observed in patients with GCA due to the improved early recognition and treatment of GCA. Prompt initiation of glucocorticoids remains to be the mainstay treatment of GCA. However, relapses are frequent when glucocorticoids are tapered. The clinical features at the time of relapses are generally similar to those found at the time of disease diagnosis. In this sense, they usually present with headache or PMR. However, at the time of relapses, irreversible vision loss or skin manifestations are generally not observed. ${ }^{20}$ In patients with refractory or relapsing GCA or in those at risk of developing side-effects related to glucocorticoids, adjuvant therapy is usually required. ${ }^{21}$
Table I Cutaneous Lesions of Giant Cell Arteritis

\begin{tabular}{|l|l|l|}
\hline $\begin{array}{l}\text { Ischemic } \\
\text { Mucocutaneous } \\
\text { Manifestations }\end{array}$ & $\begin{array}{l}\text { Nodules and } \\
\text { Panniculitis-Like } \\
\text { Lesions }\end{array}$ & $\begin{array}{l}\text { Cutaneous } \\
\text { Diseases } \\
\text { Associated with } \\
\text { GCA }\end{array}$ \\
\hline - Scalp necrosis & - Cutaneous nodules & - Generalized granu- \\
- Tongue necrosis & $\begin{array}{l}\text { Cutaneous lesions } \\
\text { loma annulare } \\
\text { - Lip necrosis }\end{array}$ & $\begin{array}{l}\text { Basal cell carcinoma } \\
\text { erythema nodosum }\end{array}$ \\
\hline
\end{tabular}

In recent years, there has been increased awareness of GCA among clinicians. A multidisciplinary approach can be decisive for early diagnosis and treatment of GCA. Throughout this review, we provide an updated overview focused on the cutaneous manifestations of GCA for the dermatology clinic.

We have classified the cutaneous manifestations of GCA into three groups according to their nature: ischemic manifestations, nodules, and panniculitis-like lesions, and cutaneous diseases that are not directly caused by GCA but that can be found in the setting of GCA (Table 1).

\section{Ischemic Mucocutaneous Manifestations of Giant Cell Arteritis}

Ischemic lesions in GCA occur as a consequence of severe arterial occlusions of inflamed vessels. These lesions are typically found on the scalp and tongue. Ischemic vascular damage can progress to necrosis if diagnosis and therapy onset is delayed.

\section{Scalp Necrosis}

Necrosis of the scalp in a patient with GCA was first described by Cooke et al in $1946 .^{22}$ It may affect one side or may extend to large areas involving the entire scalp $^{23}$ (Figure 1). It is considered a result of the severe affection of the vessels supplying the temporal region of the scalp that include the temporal, frontal, retro-auricular, and occipital arteries.

Scalp necrosis has been recognized as a marker of severity and poor prognosis. ${ }^{23,24}$ In this regard, Soderstrom et $\mathrm{al}^{23}$ found that 9 of 13 GCA patients who presented scalp necrosis developed irreversible visual loss. Further on, Tsianakas et $\mathrm{al}^{24}$ conducted an extensive literature review including 78 cases of scalp necrosis. They found that $31.5 \%$ of patients developed vision loss and $38.4 \%$ other visual defects. ${ }^{24}$ The presence of scalp 


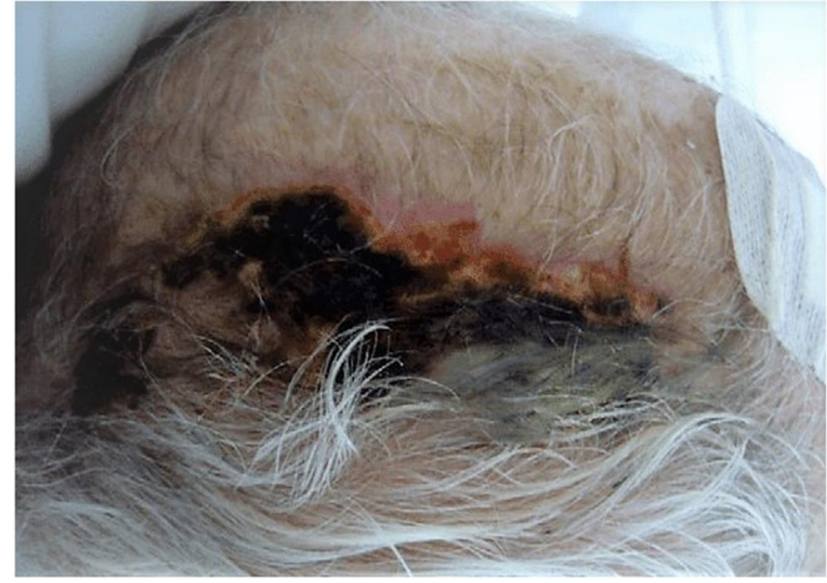

Figure I Skin necrosis over the temporoparietal scalp area in a patient with giant cell arteritis.

Note: Courtesy of Dr. J Sánchez Martín.

necrosis has been also associated with high rates of mortality, ranging from $20.2 \%$ to $38 \%{ }^{23-27}$

In the initial stages of scalp necrosis, administration of high doses of glucocorticoids can slow its progression. However, when necrosis is established, surgery is often required to remove all necrotic tissue and minimize the risk of severe bacterial infections. ${ }^{24,28,29}$ Skin-graft may be needed to improve wound closure. Noteworthy, no single case of scalp necrosis recurrence has been reported after the onset of appropriate treatment. ${ }^{24}$

\section{Tongue Necrosis}

GCA can cause several symptoms in the tongue including pain, swelling, and burning. ${ }^{30,31}$ Some of these manifestations might be more frequent than expected. In this regard, glossitis has been described in up to $10 \%$ of GCA patients in retrospective series. ${ }^{19}$ Episodes of lingual ischemia presenting with recurrent blanching of the tongue have been described in severe cases of GCA. ${ }^{32}$ Interestingly, histological evidence of lingual arteritis in the tongue biopsy of GCA patients was reported for the first time in the early 1960s. ${ }^{33}$

Lingual necrosis is rarely found due to the rich blood supply of the tongue. However, the lingual artery, which originates from the external carotid, can be affected in patients with severe GCA leading to occlusion and ischemia. ${ }^{33}$ Necrosis usually occurs in the anterior twothirds of the tongue ${ }^{18}$ (Figure 2).

A recent literature review identified 25 published cases of tongue necrosis in GCA patients between 2002 and $2015 .{ }^{34}$ Older females were the most affected. Lingual necrosis was usually accompanied by other ischemic

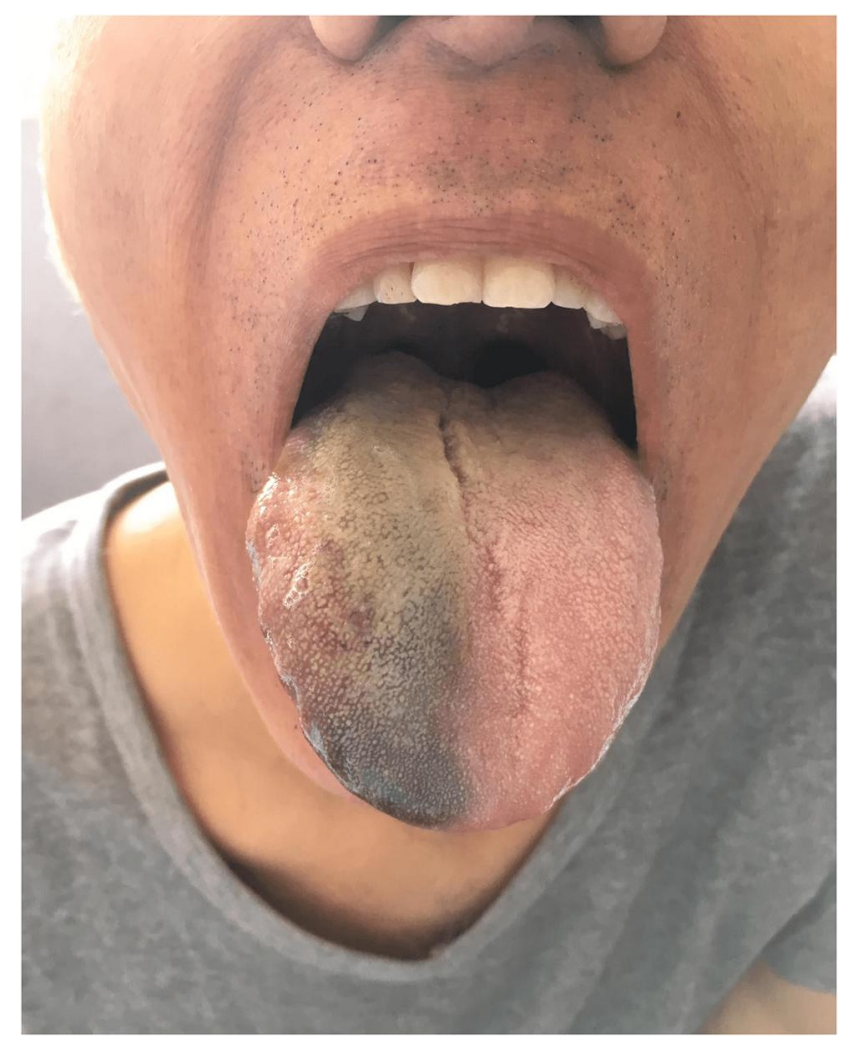

Figure 2 Swelling tongue with anterior ischemic lingual necrosis in a patient with giant cell arteritis.

Note: Courtesy of Dr. J Sánchez Martín and The Spanish Society of Rheumatology.

cranial symptoms. Higher rates of visual manifestations were reported to be present in $38 \%$ of patients. ${ }^{34}$ Some cases of concomitant scalp and tongue necrosis, and even lip necrosis, have been reported. ${ }^{35,36}$ Tongue necrosis is also considered an unfavorable prognostic sign. ${ }^{37}$

Differential diagnoses in patients presenting with lingual necrosis should include malignancy, previous exposure to radiation therapy, infections, use of some drugs such as vasopressin, chemotherapy or ergotamine, embolisms, and other systemic vasculitis. ${ }^{37}$

Most patients respond to high-dose glucocorticoid therapy, but in refractory cases, adjuvant therapy with conventional immunosuppressive drugs and/or biologic therapy may be needed. ${ }^{34}$ Rare cases of severe extensive necrosis of the tongue progressing to auto-amputation of the necrotic tissue have been reported in the absence of early response to usual treatment. ${ }^{37}$

\section{Nodules and Panniculitis-Like Lesions in Giant Cell Arteritis}

Panniculitis is uncommon in patients with large vessel vasculitis. Erythema nodosum has been described in 
patients with Bechet's disease, polyarteritis nodosa, and Takayasu's arteritis but is rarely found in GCA patients. These vasculitis share some common presenting features, and all can affect medium-sized vessels of the skin. However, there are important clinical and epidemiological differences that help us to differentiate them. Takayasu's arteritis is a large vessel vasculitis that affects younger patients than GCA, usually under 40 years of age. Systemic symptoms and limb claudication are common symptoms of both GCA and Takayasu's arteritis. However, cranial and visual symptoms are infrequent in Takayasu's arteritis. Polyarteritis nodosa is a rare systemic necrotizing vasculitis with multisystemic involvement that usually affects patients in the sixth decade of life. Unlike GCA, skin lesions, renal failure, abdominal pain, muscle, and neurologic involvement are common findings in polyarteritis nodosa. By contrast, Behçet's disease can involve blood vessels of all sizes (small, medium, and large). It is characterized by the presence of recurrent mucocutaneous ulcers, uveitis, neurological disease, arthritis, and skin lesions which are uncommonly found in GCA.

Several retrospective studies have reported the presence of cutaneous lesions resembling panniculitis in patients with GCA. In these cases, a skin biopsy is always needed to exclude other entities.

\section{Cutaneous Nodules}

Cutaneous nodules on the surface of the temporal arteries can be frequently found in patients with GCA (Figure 3). However, the presence of nodules in other locations is extremely rare. Thus, other conditions should be always ruled out first.

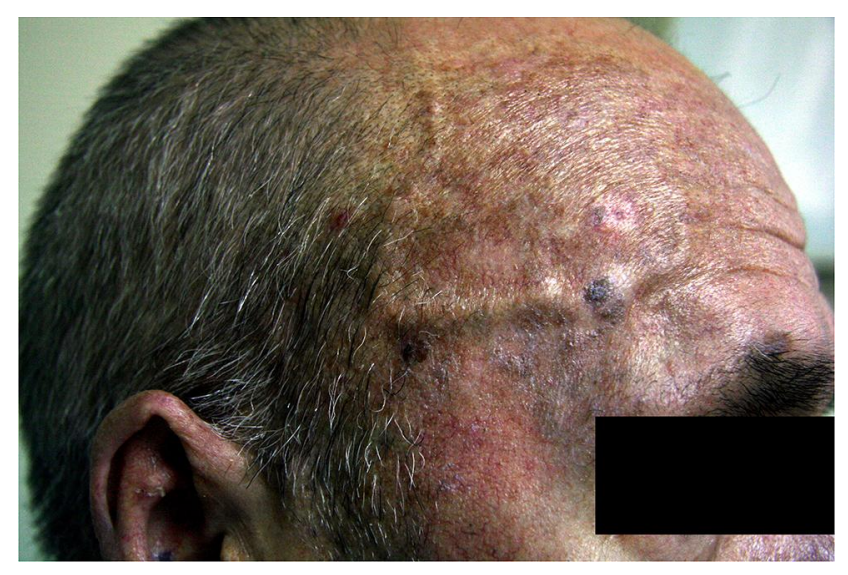

Figure 3 Cutaneous nodules on the surface of the right temporal artery. Note: Courtesy of Dr. E de Miguel.
Vivancos et $\mathrm{al}^{38}$ reported a case of GCA presenting with a supraclavicular nodule simulating a lymph node. No other symptoms apart from constitutional syndrome were present. The patient had a $2.5 \mathrm{~cm}$ indurated, tender, non-erythematous nodule in the right supraclavicular region. The rest of physical examination was normal. Laboratory data showed raised levels of erythrocyte sedimentation rate $(92 \mathrm{~mm} / 1 \mathrm{st} \mathrm{h})$. The skin biopsy showed abundant fibroadipose tissue with foci of blood vessels showing inflammatory changes consisting of GCA. Interestingly, despite the atypical presentation, the temporal artery biopsy confirmed the diagnosis of GCA. The patient experienced a good response to oral glucocorticoids that led to the resolution of the nodule.

Several case reports of cutaneous nodules mimicking breast cancer have been reported in patients with GCA. ${ }^{39-45}$ Waugh et $\mathrm{al}^{39}$ described in 1950 a case of bilateral mammary arteritis presenting with a unilateral non-tender breast lump with histologic evidence of giant cell inflammatory vasculitis. Indeed, the blood supply of the breast mainly depends on the internal mammary artery and the lateral thoracic artery which are branches of the subclavian artery. As mentioned above, GCA can affect extracranial vessels and, consequently, mammary arteries can also potentially be involved. McKendry et $\mathrm{al}^{43}$ suggested that breast nodules may be underreported in GCA patients given their non-specific aspect that can resemble a benign fibrocystic disease.

\section{Cutaneous Lesions Resembling Erythema Nodosum}

Cutaneous lesions resembling erythema nodosum have been described in patients with GCA, particularly in patients with extracranial large vessel involvement. In this regard, Goldberg et $\mathrm{al}^{46}$ reported a patient with biopsy-proven GCA and extracranial LVV involvement presenting with claudication of the lower extremities who developed cutaneous lesions on the pretibial areas of her legs that were clinically indistinguishable from erythema nodosum. The skin biopsy revealed giant cell vasculitis of the subcutaneous and septal vessels. It is worth remembering that the classic histopathological picture of erythema nodosum is septal panniculitis without vasculitis. Multinucleated giant cells may be seen but restricted to the septae of the subcutaneous fat lobules. $^{47}$ 


\section{Cutaneous Diseases Associated with Giant Cell Arteritis Generalized Granuloma Annulare and GCA}

The coexistence of generalized granuloma annulare and GCA has been anecdotally reported in the literature. ${ }^{48-52}$ Both conditions share common immunopathologic features characterized by elastic tissue damage, granulomatous inflammation, and T-cell infiltrates. In addition, similar HLA genetic susceptibility has been observed in both entities. In this regard, a significantly increased frequency of $H L A-B^{*} 15$ alleles has been described in both granuloma annulare ${ }^{53}$ and GCA. ${ }^{54}$

Generalized granuloma annulare is considered a widespread form of granuloma annulare and accounts for $10 \%$ to $15 \%$ of all cases. ${ }^{55}$ It usually presents with disseminated annular and erythematous plaques on the trunk and limbs. In comparison to the localized form, it usually affects older patients, has a prolonged course of the disease, and has a worse response to conventional treatment. ${ }^{56,57}$ Skin biopsies usually show degeneration of the elastic fibers with loss of peripheral microfibrils and abnormal elastic matrix along with the presence of granulomatous infiltrate. ${ }^{58}$ Likewise, in GCA, disruption of the internal elastic lamina and the presence of granulomatous giant cell infiltrate are found in temporal biopsy samples. ${ }^{59}$

To the best of our knowledge, only five cases of concomitant disseminated granuloma annulare and GCA have been reported. ${ }^{48-52}$ In 4 of these 5 patients, the disseminated granuloma annulare preceded GCA, whereas in one patient the diagnosis of GCA was made three years before granuloma annulare. All patients were successfully treated with glucocorticoids. ${ }^{52}$

\section{Basal Cell Carcinoma and GCA}

Accumulating evidence supports that there is no overall increased incidence of malignancy in patients with GCA. ${ }^{60-63}$ However, some cases of concomitant nonmelanoma skin cancer and GCA have been reported. ${ }^{64,65}$ Mahe et al ${ }^{65}$ reported a patient referred to the dermatology clinic due to a left temporal ulcerating skin lesion. Excision of the cutaneous lesion revealed an ulcerating basal cell carcinoma. Interestingly, the skin biopsy included a portion of the temporal artery which showed histologic findings consistent with GCA. A detailed clinical history revealed that the patient also had mild left-sided headache and symptoms resembling
PMR that had gone unnoticed. The presence of GCA and basal cell carcinoma in this patient was probably a coincidence. This case report highlights that in the absence of a careful histologic examination, the diagnosis of GCA would probably have been delayed. However, solid evidence-based studies have shown that GCA is not associated with an increased risk of malignancies, including non-melanoma skin cancer. ${ }^{60-63}$

Given that both GCA and basal cell carcinoma are more frequently found in elderly patients, it is important to perform a careful physical examination and ask for symptoms suggesting GCA in atypical cases presenting with cutaneous lesions in the temple areas.

\section{Diagnosis Approach in Giant Cell Arteritis}

The diagnosis of GCA is mainly based on clinical and laboratory findings. Traditionally, temporal artery biopsy has been used to confirm GCA diagnosis. ${ }^{66}$ However, recently, imaging techniques are increasingly being used for GCA diagnosis. ${ }^{21}$ In this regard, ultrasound of temporal and axillary arteries is now recommended as the first imaging modality in patients with suspected GCA. ${ }^{67}$

The American College of Rheumatology (ACR) proposed in 1990 a set of classification criteria for GCA. ${ }^{68}$ These criteria include age at disease 50 years or older, new onset of headache, temporal artery abnormality on physical examination of the temporal arteries, positive temporal artery biopsy, and an erythrocyte sedimentation rate (ESR) equal to or greater than $50 \mathrm{~mm} / 1 \mathrm{st}$ hour. At least 3 of these 5 criteria are needed to classify a patient as having GCA. The 1990 ACR classification criteria for GCA identify most patients with the classic cranial pattern of GCA but are not useful to identify GCA patients presenting with extracranial large vessel involvement. In these patients, modern imaging techniques are needed to make the diagnosis. Ultrasound, Computed Tomography Angiography (CT-A), Magnetic Resonance Imaging Angiography (MRI-A), and 18F-fluorodeoxyglucose positron emission tomography (18F-FDG PET/CT) have shown high sensitivity and specificity in detecting the presence of extracranial LVV GCA. ${ }^{67}$

A complete clinical history and physical examinations should be performed in patients presenting with cutaneous lesions in the setting of GCA suspicion. The main clinical symptoms and signs of GCA are summarized in Table 2. Careful palpation of the superficial temporal arteries and 
Table 2 Main Clinical Symptoms and Signs of Giant Cell Arteritis

\begin{tabular}{|c|c|c|c|}
\hline & Classic Cranial Ischemic Features & $\begin{array}{l}\text { LVV Extracranial } \\
\text { Features }\end{array}$ & $\begin{array}{l}\text { Non-Specific } \\
\text { Manifestations }\end{array}$ \\
\hline Main symptoms & $\begin{array}{l}\text { - New onset headache, often in the temporal area. } \\
\text { - Scalp tenderness } \\
\text { - Jaw and/or tongue claudication } \\
\text { - Carotidynia } \\
\text { - Acute visual symptoms (amaurosis fugax, acute vision loss, } \\
\text { diplopia). } \\
\text { - Associated polymyalgia rheumatica symptoms. } \\
\text { - Temporal artery abnormalities (tenderness, thickness, nodules, } \\
\text { - pulseless). } \\
\text { occlusion on ophthalmologic examination. }\end{array}$ & $\begin{array}{l}\text { - Limb pain and } \\
\text { claudication } \\
\text { - Refractory polymyalgia } \\
\text { rheumatica symptoms } \\
\text { - Pulse asymmetry } \\
\text { - Arterial pressure } \\
\text { asymmetry } \\
\text { - Peripheral arterial } \\
\text { bruits }\end{array}$ & $\begin{array}{l}\text { - Low-grade fever } \\
\text { - Weight loss } \\
\text { - Fatigue/malaise }\end{array}$ \\
\hline
\end{tabular}

their branches is mandatory. Palpate the temporal arteries immediately in front of the tragus of the ear and up along the temple in search of painful, tender, enlarged, nodular, or pulseless temporal arteries. In addition, it is also important to check the pulse in the arms and legs in patients with a suspicion of extracranial LVV GCA, looking for the presence and symmetry of the pulses.

Routine laboratory testing should include red blood cell count, platelets, erythrocyte sedimentation rate, C-reactive protein, liver, and kidney function test, and urinalysis. Most GCA patients show markedly increased acute phase reactants (ESR and C-reactive protein) at the time of disease diagnosis. ${ }^{69}$ Thrombocytosis is a common finding in patients with GCA and is associated with a more severe disease.

It is recommended to start glucocorticoids immediately when there is a high suspicion of GCA and refer the patient to a specialist team for further assessment as soon as possible. ${ }^{70}$ Figure 4 shows an initial management work-

\section{Patients presenting skin lesions suggestive of GCA}

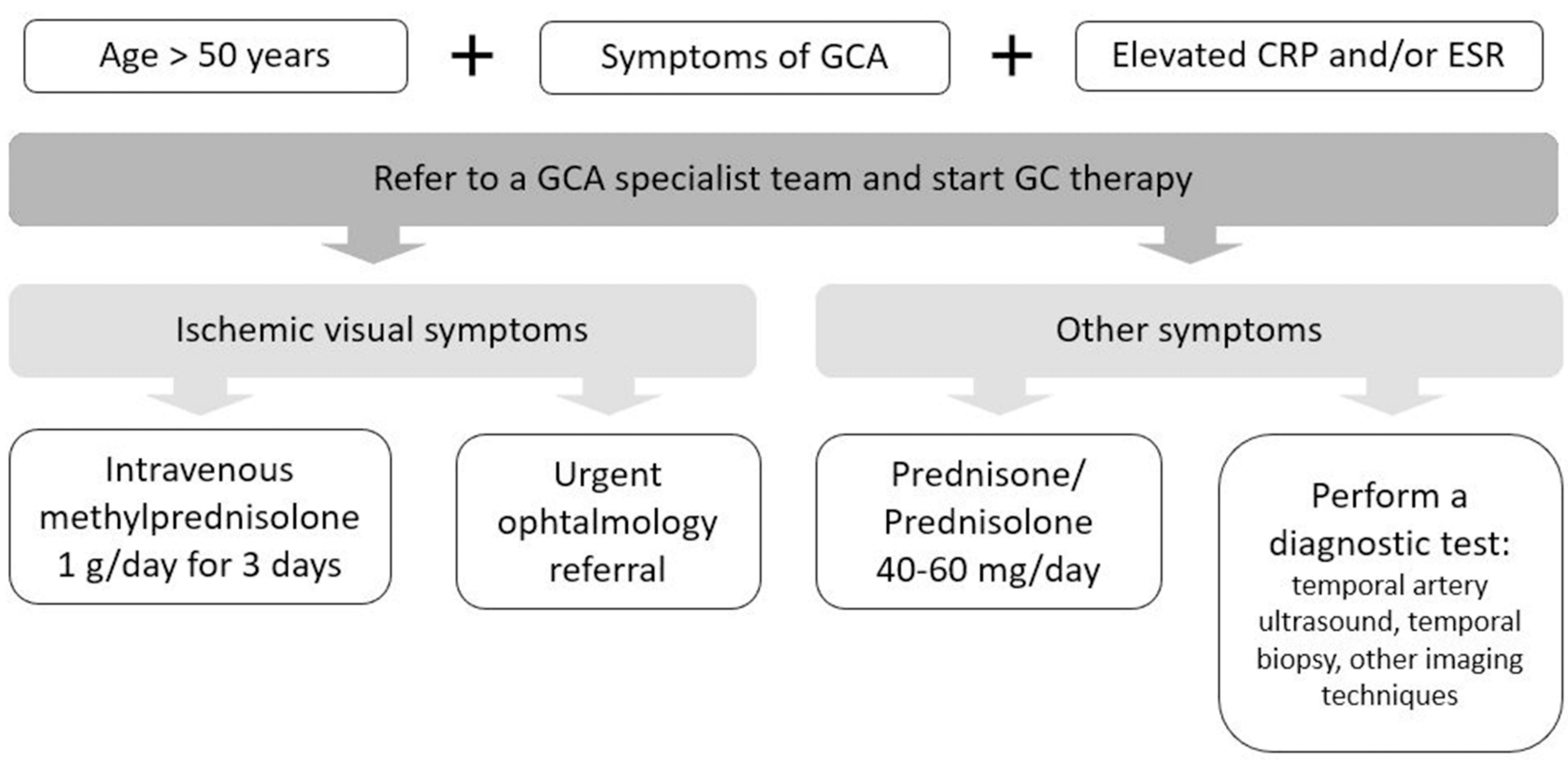

Figure 4 Diagnostic work-up and management of patients with suspected giant cell arteritis presenting with cutaneous lesions. Abbreviations: CRP, C-reactive protein; ESR, erythrocyte sedimentation rate; GCA, giant cell arteritis, GC, glucocorticoids. 
up for patients presenting with cutaneous lesions in the setting of GCA suspicion.

\section{Treatment of Giant Cell Arteritis}

Glucocorticoids remain the cornerstone of GCA treatment. High-dose glucocorticoid therapy is needed to induce remission in patients with GCA. There is general agreement on the use of an initial dose of 40-60 $\mathrm{mg} /$ prednisone or prednisolone/day for 3-4 weeks. Nevertheless, in patients who present with severe ischemic manifestations, particularly if visual impairment exists, it is recommended to administrate intravenous methylprednisolone pulse therapy (1g daily for 3 consecutive days). ${ }^{21,70,71}$ In most cases, improvement of ischemic symptoms and decrease of acute phase reactants is observed within the first 24 to 72 hours after the onset of glucocorticoid therapy. The probability of visual recovery is low when blindness is established. Therefore, the onset of treatment should be not delayed if GCA is suspected.

Once GCA symptoms are controlled, glucocorticoids can be progressively tapered. Experts from the European League Against Rheumatism (EULAR) recommend reducing the prednisone/prednisolone dose to a target dose of 15-20 mg/day within 2-3 months and after 1 year to $\leq$ $5 \mathrm{mg} /$ day. $^{70}$ Based on our experience, we usually taper $5 \mathrm{mg}$ of prednisone every 2 weeks until a prednisone dose of $25 \mathrm{mg} /$ day is reached. Thereafter, we reduce prednisone dose more slowly by $2.5 \mathrm{mg}$ every $2-4$ weeks up to $10 \mathrm{mg}$ /day. Later, we taper prednisone dose by approximately $2.5 \mathrm{mg}$ every 2 months. ${ }^{21,71}$

Adjuvant therapy is recommended in patients with refractory or relapsing GCA or in those patients with increased risk of glucocorticoid-related adverse effects. ${ }^{70}$ In this regard, conventional immunosuppressive drugs, such as methotrexate, have shown some efficacy in refractory GCA. ${ }^{72}$ Nowadays, tocilizumab (TCZ) is the only approved biologic agent by the European Medicine Agency (EMA) and the Food and Drug Administration (FDA) for the treatment of GCA. TCZ is a monoclonal anti-interleukin 6 (IL-6) receptor that has proved to be effective to induce remission, prevent relapses and decrease the cumulative prednisone dose in patients with GCA in both clinical trials and real-life studies. ${ }^{73-75}$

\section{Conclusions}

A multidisciplinary approach is needed to provide the best care for GCA patients. A high level of suspicion of GCA among dermatologists may be crucial for early diagnosis and therapy onset.
Cutaneous manifestations are not frequent in GCA, but when present they may reflect severe affection and poor prognosis. In particular, necrosis of the scalp or tongue may warn physicians about the possibility of GCA in elderly patients. Prompt initiation of glucocorticoids and referral to a GCA specialist team is recommended to prevent serious complications.

\section{Acknowledgments}

Authors thank Dr. Julio Sánchez Martin from the Rheumatology Department of Hospital 12 de Octubre, Madrid (Spain) for the assigment of Figure 1 and 2, Dr. Eugenio de Miguel from the Rheumatology Department of Hospital La Paz, Madrid (Spain) for the assignment of Figure 3 and the Spanish Society of Rheumatology for the generous contribution of the image to Figure 2.

\section{Funding}

This line of research on vasculitis was partially supported by RETICS Programs, RD08/0075 (RIER), RD12/0009/ 0013 and RD16/0012 from "Instituto de Salud Carlos III" (ISCIII) (Spain).However, this study did not receive any specific grant from funding agencies in the commercial or not-for-profit sectors.

\section{Disclosure}

DP-P is supported by a research contract from the Carlos III Health Institute of Spain (Rio Hortega program, ref. CM20/ 00006) and has received grants/research supports from UCB Pharma, Roche, Sanofi, Pfizer, AbbVie and Lilly and the Spanish Foundation of Rheumatology (FERGALAPAGOS program). SC has received grants/research support from Amgen, MSD and Pfizer, and has received consultation fees in company sponsored speaker's bureau from Amgen, Lilly, MSD, Novartis, Sanofi, Sobi, Stata and UCB. BA-M received grants/research supports from Kern Pharma, AbbVie, Pfizer, Celgene and GSK. RB received grants/research supports from Abbvie, MSD and Roche, and had consultation fees/participation in company sponsored speaker's bureau from Abbvie, Lilly, Pfizer, Roche, Bristol-Myers, Janssen, UCB Pharma and MSD. MAG-G has received grants/research supports from Abbvie, Novartis, MSD. Janssen and Roche and had consultation fees/participation in company sponsored speaker's bureau from Abbvie, Pfizer, Roche, Sanofi, Lilly, Celgene, Sobi and MSD. The authors report no other conflicts of interest in this work. 


\section{References}

1. Gonzalez-Gay MA, Vazquez-Rodriguez TR, Lopez-Diaz MJ, et al. Epidemiology of giant cell arteritis and polymyalgia rheumatica. Arthritis Rheum. 2009;61:1454-1461. doi:10.1002/art.24459

2. Salvarani C, Cantini F, Boiardi L, Hunder GG. Polymyalgia rheumatica and giant-cell arteritis. $N$ Engl J Med. 2002;347:261-271. doi:10.1056/NEJMra011913

3. Carmona FD, González-Gay MA, Martín J. Genetic component of giant cell arteritis. Rheumatol Oxf Engl. 2014;53:6-18. doi:10.1093/ rheumatology/ket231

4. Carmona FD, Mackie SL, J-e M, et al. A large-scale genetic analysis reveals a strong contribution of the HLA class II region to giant cell arteritis susceptibility. Am J Hum Genet. 2015;96:565-580. doi:10. 1016/j.ajhg.2015.02.009

5. Prieto-Peña D, Remuzgo-Martínez S, Ocejo-Vinyals JG, et al. Cranial and extracranial giant cell arteritis share similar HLA-DRB1 association. Semin Arthritis Rheum. 2020;50(5):897-901. doi:10.10 16/j.semarthrit.2020.07.004

6. Weyand CM, Goronzy JJ. Pathogenic mechanisms in giant cell arteritis. Cleve Clin J Med. 2002;69(Suppl 2):SII28-SII32.

7. Watanabe R, Goronzy JJ, Berry G, Liao YJ, Weyand CM. Giant cell arteritis: from pathogenesis to therapeutic management. Curr Treat Options Rheumatol. 2016;2:126-137. doi:10.1007/s40674016-0043-x

8. Gonzalez-Gay MA, Barros S, Lopez-Diaz MJ, Garcia-Porrua C, Sanchez-Andrade A, Llorca J. Giant cell arteritis: disease patterns of clinical presentation in a series of 240 patients. Medicine. 2005;84:269-276. doi:10.1097/01.md.0000180042.42156.d1

9. Gonzalez-Gay MA, Castañeda S, Llorca J. Giant cell arteritis: visual loss is our major concern. $J$ Rheumatol. 2016;43:1458-1461. doi: $10.3899 /$ jrheum. 160466

10. González-Gay MA, García-Porrúa C, Llorca J, et al. Visual manifestations of giant cell arteritis trends and clinical spectrum in 161 patients. Medicine. 2000;79:283-292.

11. Gonzalez-Gay MA, Vazquez-Rodriguez TR, Gomez-Acebo I, et al. Strokes at time of disease diagnosis in a series of 287 patients with biopsy-proven giant cell arteritis. Medicine. 2009;88:227-235. doi:10.1097/MD.0b013e3181af4518

12. González-Gay MA, Matteson EL, Castañeda S. Polymyalgia rheumatica. Lancet Lond Engl. 2017;390:1700-1712. doi:10.1016/ S0140-6736(17)31825-1

13. Prieto-Peña D, Martínez-Rodríguez I, Loricera J, et al. Predictors of positive 18F-FDG PET/CT-scan for large vessel vasculitis in patients with persistent polymyalgia rheumatica. Semin Arthritis Rheum. 2019;48:720-727. doi:10.1016/j.semarthrit.2018.05.007

14. González-Gay MA, Prieto-Peña D, Calderón-Goercke M, AtienzaMateo B, Castañeda S. Giant cell arteritis: more than a cranial disease. Clin Exp Rheumatol. 2020;38(Suppl 124):15-17.

15. González-Gay MA, Prieto-Peña D, Martínez-Rodríguez I, et al. Early large vessel systemic vasculitis in adults. Best Pract Res Clin Rheumatol. 2019;33:101424. doi:10.1016/j.berh.2019.06.006

16. Kermani TA, Warrington KJ, Crowson CS, et al. Large-vessel involvement in giant cell arteritis: a population-based cohort study of the incidence-trends and prognosis. Ann Rheum Dis. 2013;72: 1989-1994. doi:10.1136/annrheumdis-2012-202408

17. Baum EW, Sams WM, Payne RR. Giant cell arteritis: a systemic disease with rare cutaneous manifestations. $J$ Am Acad Dermatol. 1982;6:1081-1088. doi:10.1016/S0190-9622(82)70094-5

18. Chasset F, Francès FC. Cutaneous manifestations of medium- and large-vessel vasculitis. Clin Rev Allergy Immunol. 2017;53:452-468. doi:10.1007/s12016-017-8612-9

19. Kinmont PD, Mccallum DI. SKIN MANIFESTATIONS OF GIANT-CELL ARTERITIS. $\mathrm{Br} J$ Dermatol. 1964;76:299-308. doi:10.1111/j.1365-2133.1964.tb14533.x
20. Martinez-Lado L, Calviño-Díaz C, Piñeiro A, et al. Relapses and recurrences in giant cell arteritis: a population-based study of patients with biopsy-proven disease from northwestern Spain. Medicine (Baltimore). 2011;90:186-193. doi:10.1097/MD.0b013e31821c4fad

21. González-Gay MA, Pina T, Prieto-Peña D, Calderon-Goercke M, Blanco R, Castañeda S. Current and emerging diagnosis tools and therapeutics for giant cell arteritis. Expert Rev Clin Immunol. 2018;14:593-605. doi:10.1080/1744666X.2018.1485491

22. Cooke WT, Cloake PCP, Govan ADT, Colbeck JC. Temporal arteritis: a generalized vascular disease. $Q J$ Med. 1946;15:47-75. doi:10.1093/qjmed/15.57.47

23. Soderstrom CW, Seehafer JR. Bilateral scalp necrosis in temporal arteritis. A rare complication of Horton's disease. Am J Med. 1976;61:541-546. doi:10.1016/0002-9343(76)90335-1

24. Tsianakas A, Ehrchen JM, Presser D, et al. Scalp necrosis in giant cell arteritis: case report and review of the relevance of this cutaneous sign of large-vessel vasculitis. J Am Acad Dermatol. 2009;61: 701-706. doi:10.1016/j.jaad.2008.11.913

25. Matteson EL, Gold KN, Bloch DA, Hunder GG. Long-term survival of patients with giant cell arteritis in the American College of Rheumatology giant cell arteritis classification criteria cohort. Am J Med. 1996;100:193-196. doi:10.1016/S0002-9343(97)89458-2

26. González-Gay MA, Blanco R, Abraira V, et al. Giant cell arteritis in Lugo, Spain, is associated with low longterm mortality. $J$ Rheumatol. 1997;24:2171-2176.

27. Gran JT, Myklebust G, Wilsgaard T, Jacobsen BK. Survival in polymyalgia rheumatica and temporal arteritis: a study of 398 cases and matched population controls. Rheumatol Oxf Engl. 2001;40:12 38-1242. doi:10.1093/rheumatology/40.11.1238

28. Idoudi S, Ben Kahla M, Mselmi F, et al. Scalp necrosis revealing severe giant-cell arteritis. Case Rep Med. 2020;2020:8130404. doi: $10.1155 / 2020 / 8130404$

29. Akram Q, Knight S, Saravanan R. Bilateral scalp necrosis as a rare but devastating complication of giant cell arteritis. Clin Rheumatol. 2015;34:185-187. doi:10.1007/s10067-014-2792-y

30. Henderson AH. Tongue pain with giant cell arteritis. $\mathrm{Br}$ Med $J$. 1967;4:337. doi:10.1136/bmj.4.5575.337

31. Grant SWJ, Underhill HC, Atkin P. Giant cell arteritis affecting the tongue: a case report and review of the literature. Dent Update. 2013;40:669-70,673-4, 677. doi:10.12968/denu.2013.40.8.669

32. Grahame R, Bluestone R, Holt PJ. Recurrent blanching of the tongue due to giant cell arteritis. Ann Intern Med. 1968;69:781-782. doi:10.7326/0003-4819-69-4-781

33. Reed C, Inlis MJ. Acute massive gangrene of tongue. Br Med J. 1965;2:575-576. doi:10.1136/bmj.2.5461.575

34. Sobrinho RA, de Lima KC, Moura HC, et al. Tongue necrosis secondary to giant cell arteritis: a case report and literature review. Case Rep Med. 2017;2017:1-5. doi:10.1155/2017/6327437

35. Pogrel MA. Necrosis of the upper lip from giant-cell arteritis. $J$ Oral Maxillofac Surg off. 1985;43:300-302. doi:10.1016/0278-2391(85) 90294-0

36. Kumar R, Gupta H, Jadhav A, Khadilkar S. Bitemporal scalp, lip and tongue necrosis in giant cell arteritis: a rare presentation. Indian J Dermatol. 2013;58:328. doi:10.4103/0019-5154.113980

37. Zaragoza JR, Vernon N, Ghaffari G. Tongue necrosis as an initial manifestation of giant cell arteritis: case report and review of the literature. Case Rep Rheumatol. 2015;2015. doi:10.1155/2015/ 901795

38. Vivancos J, Bosch X, López-Soto A, Font J, Ribera JM, Ingelmo M. Giant cell arteritis presenting as a supraclavicular nodule. Ann Rheum Dis. 1990;49:202-203. doi:10.1136/ard.49.3.202-c

39. Waugh TR. Bilateral mammary arteritis; report of a case. $A m$ J Pathol. 1950;26:851-861.

40. Potter BT, Housley E, Thomson D. Giant-cell arteritis mimicking carcinoma of the breast. Br Med J Clin Res Ed. 1981;282:1665-1666. doi:10.1136/bmj.282.6277.1665 
41. Stephenson TJ, Underwood JC. Giant cell arteritis: an unusual cause of palpable masses in the breast. $\mathrm{Br} J$ Surg. 1986;73:105. doi:10.1002/bjs. 1800730208

42. Cook DJ, Bensen WG, Carroll JJ, Joshi S. Giant cell arteritis of the breast. CMAJ Can Med Assoc J J Assoc Medicale Can. 1988;13 9:513-515.

43. McKendry RJ, Guindi M, Hill DP. Giant cell arteritis (temporal arteritis) affecting the breast: report of two cases and review of published reports. Ann Rheum Dis. 1990;49:1001-1004. doi:10. 1136/ard.49.12.1001

44. Meriglier E, Belhadj Chaidi R, Debouverie O, Luca L, Roblot P. Pseudo-tumeurs mammaires révélant une maladie de Horton. [Breast lesions as the presenting feature of giant cell arteritis]. Rev Med Interne. 2016;37:561-563. doi:10.1016/j.revmed.2015.09.005. French.

45. Tabbarah A, Voltaggio L. Giant cell arteritis of the breast. Arch Pathol Lab Med. 2017;141:1283-1287. doi:10.5858/arpa.2016-0285-RS

46. Goldberg JW, Lee ML, Sajjad SM. Giant cell arteritis of the skin simulating erythema nodosum. Ann Rheum Dis. 1987;46:706-708. doi:10.1136/ard.46.9.706

47. Blake T, Manahan M, Rodins K. Erythema nodosum - a review of an uncommon panniculitis. Dermatol Online J. 2014;20:22376.

48. Fukai K, Ishii M, Kobayashi H, Someda Y, Hamada T, Tsujino S. Generalized granuloma annulare in a patient with temporal arteritisare these conditions associated? Clin Exp Dermatol. 1990;15:70-72. doi:10.1111/j.1365-2230.1990.tb02027.x

49. Yáñez S, Val-Bernal JF, Peña-Sagredo JL, Jiménez-Gómez I, Vazquez-Rodriguez TR, Gonzalez-Gay MA. Generalized granuloma annulare and giant cell arteritis. Clin Exp Rheumatol. 2008;26:S108S110.

50. Shoimer I, Wismer J. Annular elastolytic giant cell granuloma associated with temporal arteritis leading to blindness. J Cutan Med Surg. 2011;15:293-297. doi:10.2310/7750.2011.10042

51. Kluger N, Riviere S, Mura F, Guillot B, Girard C. Simultaneous occurrence of generalized granuloma annulare, anterior uveitis and giant cell arteritis: coincidental or not? Presse Medicale. 2011;41:548-549. doi:10.1016/j.1pm.2011.08.006

52. Torisu Y, Horai Y, Michitsuji T, et al. Giant cell arteritis with generalized granuloma annulare. Intern Med Tokyo Jpn. 2019;58:1173-1177. doi:10.2169/internalmedicine.1978-18

53. Middleton D, Allen GE. HLA antigen frequency in granuloma annulare. $\mathrm{Br} J$ Dermatol. 1984;110:57-59. doi:10.1111/j.13652133.1984.tb07312.x

54. Gonzalez-Gay MA, Rueda B, Vilchez JR, et al. Contribution of MHC class I region to genetic susceptibility for giant cell arteritis. Rheumatol Oxf Engl. 2007;46:431-434. doi:10.1093/rheumatology/ kel324

55. Piette EW, Rosenbach M. Granuloma annulare: clinical and histologic variants, epidemiology, and genetics. J Am Acad Dermatol. 2016;75:457-465. doi:10.1016/j.jaad.2015.03.054

56. Dabski K, Winkelmann RK. Generalized granuloma annulare: clinical and laboratory findings in 100 patients. J Am Acad Dermatol. 1989;20:39-47. doi:10.1016/S0190-9622(89)70005-0

57. Nordmann TM, Kim J-R, Dummer R, Anzengruber F, Monocentric A. Retrospective analysis of 61 patients with generalized granuloma annulare. Dermatol Basel Switz. 2020;236:369-374. doi:10.1159/000507247

58. Hanna WM, Moreno-Merlo F, Andrighetti L. Granuloma annulare: an elastic tissue disease? Case report and literature review. Ultrastruct Pathol. 1999;23:33-38. doi:10.1080/019131299281815
59. Jennette JC, Falk RJ. The role of pathology in the diagnosis of systemic vasculitis. Clin Exp Rheumatol. 2007;25:S52-S56.

60. Gonzalez-Gay MA, Lopez-Diaz MJ, Martinez-Lado L, et al. Cancer in biopsy-proven giant cell arteritis. A population-based study. Semin Arthritis Rheum. 2007;37:156-163. doi:10.1016/j.semarthrit.2007. 03.006

61. Myklebust G, Wilsgaard T, Jacobsen BK, Gran JT. No increased frequency of malignant neoplasms in polymyalgia rheumatica and temporal arteritis. A prospective longitudinal study of 398 cases and matched population controls. J Rheumatol. 2002;29:2143-2147.

62. Kermani TA, Schäfer VS, Crowson CS, et al. Malignancy risk in patients with giant cell arteritis: a population-based cohort study. Arthritis Care Res. 2010;62:149-154.

63. Hill CL, Cole A, Rischmueller M, et al. Risk of cancer in patients with biopsy-proven giant cell arteritis. Rheumatol Oxf Engl. 2010;49:756-759. doi:10.1093/rheumatology/kep409

64. LeBoit PE, Davis-Reed L. Light microscopy: clues to systemic disease in reexcision specimens of basal cell carcinoma. Am J Dermatopathol. 1999;21:361-364. doi:10.1097/00000372-199908 000-00009

65. Mahe E, Demellawy DE, Bane A, Alowami S. Giant cell temporal arteritis associated with overlying basal cell carcinoma: co-incidence or connection? Rare Tumors. 2012;4:e46. doi:10.4081/rt.2012.e46

66. Gonzalez-Gay MA. The diagnosis and management of patients with giant cell arteritis. J Rheumatol. 2005;32:1186-1188.

67. Dejaco C, Ramiro S, Duftner C, et al. EULAR recommendations for the use of imaging in large vessel vasculitis in clinical practice. Ann Rheum Dis. 2018;77:636-643. doi:10.1136/annrheumdis-2017-212 649

68. Hunder GG, Bloch DA, Michel BA, et al. The American College of Rheumatology 1990 criteria for the classification of giant cell arteritis. Arthritis Rheum. 1990;33:1122-1128. doi:10.1002/art.1780 330810

69. Gonzalez-Gay MA, Lopez-Diaz MJ, Barros S, et al. Giant cell arteritis: laboratory tests at the time of diagnosis in a series of 240 patients. Medicine. 2005;84:277-290. doi:10.1097/01.md.00001800 43.19285.54

70. Hellmich B, Agueda A, Monti S, et al. 2018 update of the EULAR recommendations for the management of large vessel vasculitis. Ann Rheum Dis. 2020;79:19-30.

71. González-Gay MÁ, Pina T, Prieto-Peña D, Calderon-Goercke M, Gualillo O, Castañeda S. Treatment of giant cell arteritis. Biochem Pharmacol. 2019;165:230-239.

72. Mahr AD, Jover JA, Spiera RF, et al. Adjunctive methotrexate for treatment of giant cell arteritis: an individual patient data meta-analysis. Arthritis Rheum. 2007;56:2789-2797. doi:10.1002/ art.22754

73. Stone JH, Tuckwell K, Dimonaco S, et al. Trial of tocilizumab in giant-cell arteritis. $N$ Engl J Med. 2017;377:317-328. doi:10.1056/ NEJMoa1613849

74. Loricera J, Blanco R, Hernández JL, et al. Tocilizumab in giant cell arteritis: multicenter open-label study of 22 patients. Semin Arthritis Rheum. 2015;44:717-723. doi:10.1016/j.semarthrit.2014.12.005

75. Calderón-Goercke M, Loricera J, Aldasoro V, et al. Tocilizumab in giant cell arteritis. Observational, open-label multicenter study of 134 patients in clinical practice. Semin Arthritis Rheum. 2019;49: 126-135. doi:10.1016/j.semarthrit.2019.01.003 


\section{Publish your work in this journal}

Clinical, Cosmetic and Investigational Dermatology is an international, peer-reviewed, open access, online journal that focuses on the latest clinical and experimental research in all aspects of skin disease and cosmetic interventions. This journal is indexed on CAS.
The manuscript management system is completely online and includes a very quick and fair peer-review system, which is all easy to use. Visit http://www.dovepress.com/testimonials.php to read real quotes from published authors. 